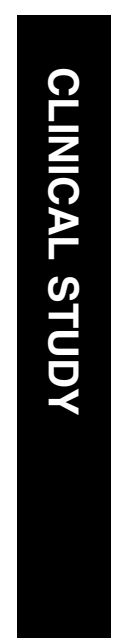

\section{Quantitative analysis of corneal microstructure in keratoconus utilising in vivo confocal microscopy}

${ }^{1}$ Ophthalmology

Department, Ninewells Hospital and Medical School, Dundee, Scotland, UK

${ }^{2}$ Department of Ophthalmology, University of Auckland, Auckland, New Zealand

Correspondence: $\mathrm{KH}$ Weed, Ophthalmology

Department, Ninewells Hospital and Medical School, Dundee, Scotland DD1 9SY, UK Tel: +44 1382632 348; Fax: +441382660130. E-mail:k.h.weed@ dundee.ac.uk

Received: 16 June 2005 Accepted in revised form: 6 January 2006 Published online: 24 February 2006

\begin{abstract}
Purpose To establish and quantify the in vivo confocal microscopic features of moderate to advanced keratoconus.

Methods Nineteen keratoconus subjects were catergorised using Orbscan-derived corneal apex power and pachymetry as exhibiting moderate $(n=7)$ and advanced $(n=12)$

keratoconus. Control subjects included 23 noncontact lens wearers (Group A) and $\mathbf{1 5}$ contact lens wearers (Group B). All subjects underwent Confoscan slit scanning in vivo confocal microscopy.
\end{abstract}

Results Compared with Group A $\left(4912 \pm 434\right.$ cells $\left./ \mathrm{mm}^{2}\right)$, basal epithelial density was significantly lower in both moderate $\left(4592 \pm 414\right.$ cells $\left./ \mathrm{mm}^{2}, P<0.05\right)$ and advanced keratoconus $\left(4530 \pm 596\right.$ cells $\left./ \mathrm{mm}^{2}, P=0.01\right)$. In comparison to Group A $\left(\mathbf{7 6 1} \pm \mathbf{1 1 8}\right.$ cells $\left./ \mathrm{mm}^{2}\right)$, anterior stroma keratocyte density was significantly greater in both moderate keratoconus $\left(883 \pm \mathbf{1 1 1}\right.$ cells $\left./ \mathrm{mm}^{2}, P=\mathbf{0 . 0 0 1}\right)$ and advanced keratoconus $(952 \pm 122$ cells/ $\left.\mathrm{mm}^{2}, \mathbf{P}<0.001\right)$. Compared to Group A $\left(504 \pm 80 \mathrm{cells} / \mathrm{mm}^{2}\right)$ posterior stroma keratocyte density was also significantly greater in advanced keratoconus $(599 \pm 97$ cells/ $\left.\mathrm{mm}^{2}, P<0.001\right)$ and posterior stromal keratocyte density appeared to increase with increasing severity of keratoconus $(P<0.05)$. However, comparing control Groups A and B, contact lens wear per se, was associated with significantly reduced $(P=0.000)$ keratocyte density in the anterior stroma $(609 \pm 66$ cells/ $\left.\mathrm{mm}^{2}\right)$ and demonstrated a trend $(P=0.056)$ in the posterior stroma $\left(470 \pm 63\right.$ cells $\left./ \mathrm{mm}^{2}\right)$. Keratoconic corneas $(429 \pm 72 \mu \mathrm{m})$ were significantly thinner than control Groups A $(508 \pm 77 \mathrm{~mm})$ and $B(495 \pm 80 \mu \mathrm{m})$. The
KH Weed ${ }^{1}$, CJ MacEwen ${ }^{1}$, A Cox ${ }^{1}$ and CNJ McGhee 2 presence of keratoconus did not affect the endothelial cell density $(P=0.54)$.

Conclusion In vivo confocal microscopy can provide insight into the microstructural changes that occur in keratoconus. Eye (2007) 21, 614-623. doi:10.1038/sj.eye.6702286; published online 24 February 2006

Keywords: in vivo confocal microscopy; keratoconus; cornea; contact lens

Introduction

Keratoconus is a noninflammatory corneal ectasia which is usually bilateral and progressive. ${ }^{1}$ The incidence of this ocular disease is approximately 1 per 2000 in the general population ${ }^{2}$; however, the precise aetiology of keratoconus is still unknown. ${ }^{3}$ Keratoconus manifests itself from a 'forme fruste' or subclinical condition, only detectable by computer video-keratoscopy ${ }^{4}(\mathrm{CVK})$ to severe eye disease with the typical biomicroscopy signs: apical protrusion with corneal thinning and scarring; Vogts striae and Fleishers ring. Initially, the treatment of choice for visual rehabilitation is rigid gas permeable contact lens wear, ${ }^{5}$ however, when this becomes unsuitable penetrating keratoplasty can be performed. ${ }^{6}$ This study's aim was to establish and quantify the in vivo confocal microscopic of moderate to advanced keratoconus and compare these data to a healthy control group.

Materials and methods

The Dundee University Scottish Keratoconus Study (DUSKS) is a long-term prospective study of 200 subjects with keratoconus resident in Tayside region of Scotland. This study has 
received local ethics committee approval and written informed consent was obtained from all participants in the current study, before investigations. All subjects were assessed in regard to prior medical, ocular and contact lens wearing history. All corneas were assessed using the Orbscan $^{\mathrm{TM}}$ (Bausch \& Lomb, UK) slit scanning system to determine the area of least corneal thickness and to establish apical power.

A subset of 19 keratoconic subjects (nine female and 10 male, mean age $40.53 \pm 2.12$ years, range $20-56$ years old) were recruited from patients attending the Ophthalmology Department, Ninewells Hospital and Medical School, Dundee. All subjects had clinical as well as videokeratographic signs of keratoconus. The severity of keratoconus was classified on the basis of corneal thickness $(<400 \mu \mathrm{m}>)$ and apical power $(<55 \mathrm{D}>)$. The mean number of contact lens wearing years for the keratoconic subjects (all RGP wearers) was $11.44 \pm 10.52$ (2-35) years.

A control group of noncontact lens wearers (Group A, nine female and 14 male, mean age $38.09 \pm 2.19$ years old) was recruited from staff working within Ninewells Hospital, as was a second control group of contact lens wearers (Group B, 11 female and four male, mean age $28.73 \pm 1.96$ years old). Group B was used only to investigate the effect of contact lens wear per se on normal corneal stromal keratocytes. In Group B, the mean number of years of RGP $(n=6)$ wear was between $10.7 \pm 3.3$ (range $6-15$ years) and $4.2 \pm 2.1$ years for the soft $(n=9)$ contact lens wearers (range 1-6 years).

Thereafter, following topical anaesthesia (Amethocaine HCL 1\%) the cornea was assessed by confocal microscopy (Confoscan ${ }^{\mathrm{TM}}$ Bausch \& Lomb) using a peasized drop of immersion gel (Viscotears, CIBA Vision) on the objective lens (Achroplan 40/0.75 WO) to couple the instrument to the cornea in a noncontact fashion. The right eye of all subjects underwent confocal microscopy. Each subject was asked to fixate on the internal flickering yellow light during the $14 \mathrm{~s}$ assessment. The objective lens was brought forward slowly towards the corneal apex, until corneal epithelial cells were seen on the video monitor. The objective lens was manually focused on the corneal endothelium and then slowly refocused on the epithelium. This allowed scanning of all the corneal layers. A $40 \times$ objective lens provided a field of view of $330 \times 240 \mathrm{um}$. Owing to the immersion fluid, the corneal epithelium was not touched during any part of the assessment.

The corneal images were detected by the light sensitive LCD camera, which were then digitised in a PC-based imaging system and stored on videotape (S-VHS). One unmasked observer then identified (1) basal epithelial cells (2) anterior and posterior keratocytes and (3) endothelial cells. The number of cells $/ \mathrm{mm}^{2}$ was then

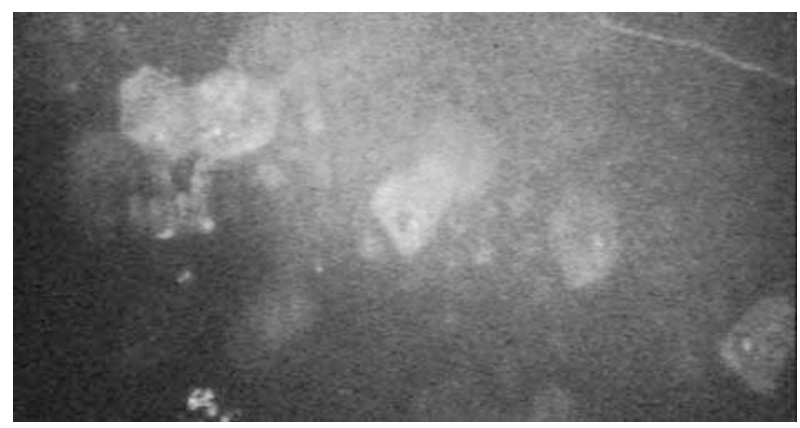

Figure 1 Desquamated superficial cells with bright cell boundaries.

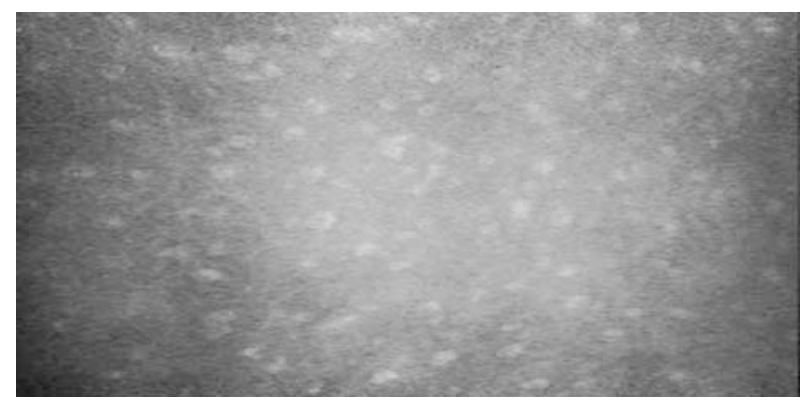

Figure 2 Intermediate basal epithelium with reflective cell bodies.

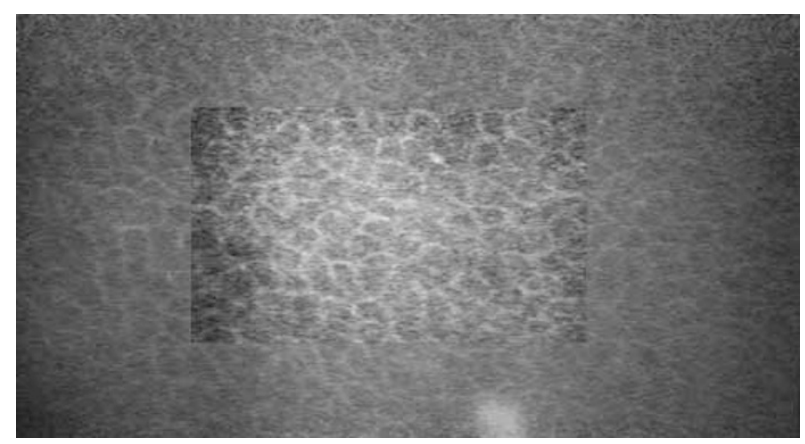

Figure 3 Basal epithelium cells in keratoconus subjects were easily visible with reflective cell borders and dark nonreflective cell bodies.

calculated by the proprietary software within the confocal microscope.

Although superficial cells and intermediate epithelial cells (Figures 1 and 2) were visible, consistency was not achieved in these layers. The confocal image quality was sufficient to allow 100\% counting of cell densities in the basal epithelium only. The basal cell layer was clearly demarcated with reflective cell borders to dark nonreflective cell bodies (Figure 3). Bowmans Layer appears as a transitional zone bordered by the basal epithelium and the anterior stroma, only distinguished by branching nerve fibres against an amorphous 




Figure 4 Anterior stromal keratocytes demonstrating oval/ ellipsoid nuclei within a moderate keratoconus subject's stroma.

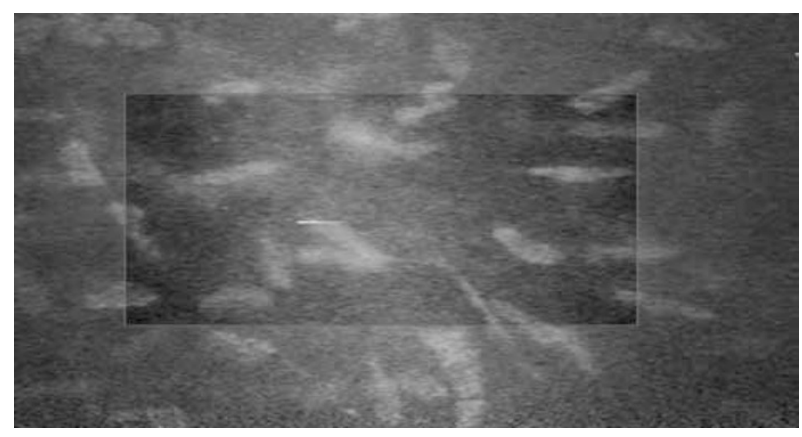

Figure 5 Posterior stromal keratocytes demonstrating elongated/spindle-shaped nuclei within a moderate keratoconus subject's stroma.

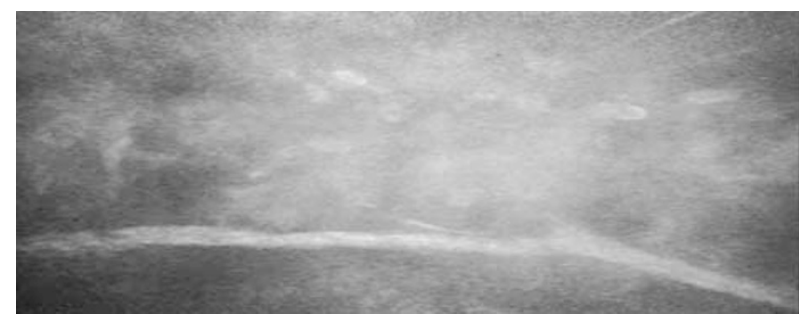

Figure 6 Anterior stromal scarring with corneal nerve innervation within a moderate keratoconus subject's stroma.

background. Corneal nerve fibres were highly reflective and were seen in both groups, innervating the area of Bowman's layer and into the anterior stroma.

In the corneal stroma the reflective keratocyte nuclei were seen against the darker ground substance; however, neither cytoplasm, cell boundaries, or collagen lamellae were visible. The keratocyte density was measured in two zones (1) just below Bowmans membrane (anterior stroma; Figure 4) and (2) just above the corneal endothelium (posterior stroma; Figure 5). In three cases within the moderate keratoconic group, stromal scarring prevented immediate visualisation of the anterior keratocytes directly under Bowmans (Figure 6).

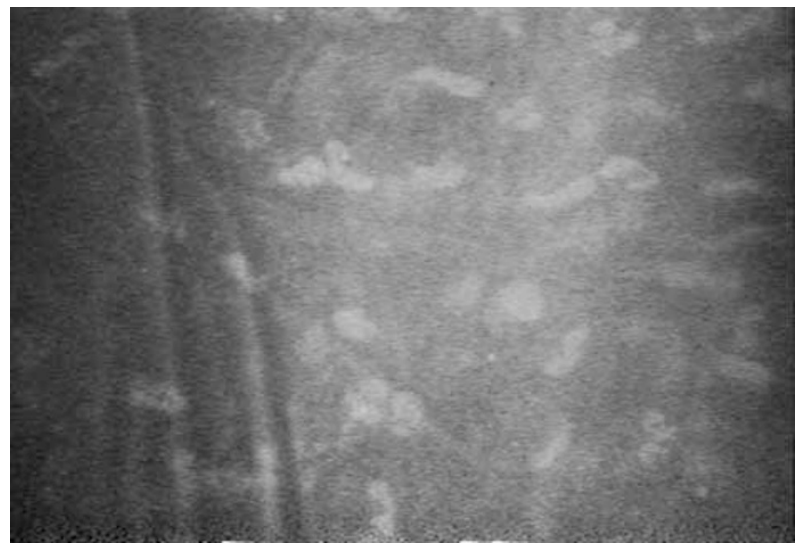

Figure 7 Stress lines within the posterior stroma of a moderate keratoconus subject. Vogts Striae are seen as dark lines within the stroma.

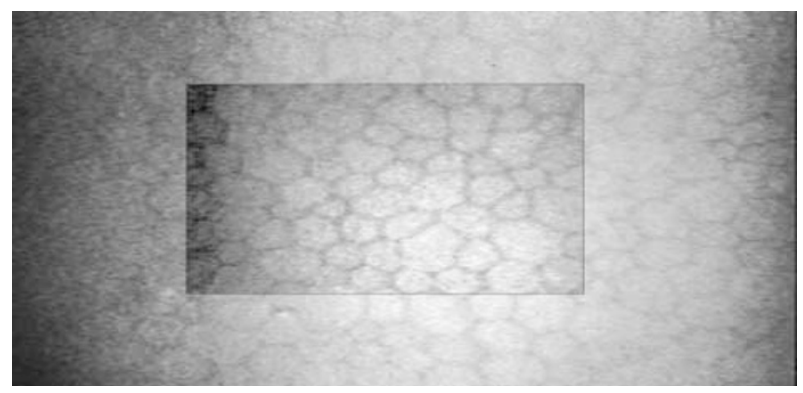

Figure 8 Endothelium mosaic of a mild keratoconus subject consisting of bright cell bodies and dark cell boundaries.

Although the immersion objective was normally positioned in front of the apparent corneal apex, in such cases the objective lens was repositioned until clarity was achieved.

The dark bands observed in the posterior stroma of keratoconic patients, (Figure 7) are similar to those observed by Somodi et $a l^{7}$ and Hollingsworth and Efron ${ }^{8}$ as being consistent with Vogt's striae. The banded appearance seen in vivo confocal microscopy was postulated to represent an irregular separation and spacing of individual collagen fibrils within the lamellae. ${ }^{8}$ Descemet's membrane was not distinguishable in either group, however, the endothelial cell mosaic was easily visible with bright cell bodies and dark cell boundaries even in cases with dense stromal scarring (Figure 8).

\section{Statistical methods}

Analysis of variance (ANOVA) was performed to determine how much of the variability in corneal morphology could be explained by the presence and 
severity of keratoconus. A contrast was performed to compare the groups with mild and moderate keratoconus against the controls and also to compare both these groups with each other. The age of the subject was included as a covariate to control for the expected effect of this variable. Levenes test for equality of variance was significant $(P=0.01)$ for the ANOVA of basal epithelial cells. In order to avoid violating the assumption of equal variance, this data were transformed (squared transformation) before analysis. Levenes test was not significant for all other dependent variables. For each of the groups the mean density is quoted along with the standard deviation.

\section{Results}

\section{Orbscan measurement and classification of disease severity}

In the keratoconus group the mean corneal apex power, measured at the thinnest part of the cornea using the Orbscan system was $52.55 \pm 4.87 \mathrm{D}$ (48-61.63 D) with a mean corneal thickness at this point of $429 \pm 72 \mu \mathrm{m}$ (300-529 $\mu \mathrm{m})$. The 'moderate' group $(n=7)$ was defined by corneal apex powers which ranged between 48 and $55 \mathrm{D}$, with a mean corneal thickness of $473 \pm 43$ (420529) $\mu \mathrm{m}$. The 'advanced' group $(n=12)$ included corneal power greater than $55 \mathrm{D}$, with a mean corneal thickness of $348 \pm 30(300-395) \mu \mathrm{m}$. The mean corneal thickness for the control Groups A and B were $508 \pm 80$ and $495 \pm 77 \mu \mathrm{m}$, respectively

\section{In vivo confocal microscopy}

The principle of confocal microscopy has been described in detail elsewhere ${ }^{9,10}$ and there were no adverse effects following assessment.

\section{Basal epithelium}

The mean basal epithelial density was $4912 \pm 434$ cells / $\mathrm{mm}^{2}$ for the noncontact lens wearing control group. There was a significantly lower basal epithelial density in those with moderate keratoconus $\left(4592 \pm 414\right.$ cells $/ \mathrm{mm}^{2}$, $P<0.05)$, and in those with advanced keratoconus ( $4530 \pm 596$ cells $\left./ \mathrm{mm}^{2}, P=0.01\right)$. The difference in basal epithelial cell density between those with moderate and advanced keratoconus was not significant. There was a nonsignificant tendency for increasing epithelial density with increasing age $(P=0.06)$. In the keratoconic group, desquamated superficial cells were easily visible with bright cell boundaries. No differences were observed within Bowmans' layer between the control and keratoconic group.

\section{Stroma}

The mean anterior keratocyte density was $761 \pm 118$ cells / $\mathrm{mm}^{2}$ for the noncontact lens wearing control group. There was a significantly greater keratocyte density in those with moderate keratoconus group ( $883 \pm 111$ cells / $\left.\mathrm{mm}^{2}, P=0.001\right)$ and in those with advanced keratoconus $\left(952 \pm 122\right.$ cells $\left./ \mathrm{mm}^{2}, P<0.001\right)$. However, the trend for increasing keratocyte density with increasing severity of keratoconus did not reach significance $(P=0.1)$. There was a nonsignificant tendency for decreasing keratocyte density with increasing age $(P=0.056)$. In comparison to the contact lens wearing control group $(609 \pm 66$ cells / $\left.\mathrm{mm}^{2}\right)$, both the keratoconic group $(P=0.000)$ and the nonwearing group $(P=0.000)$ had significantly higher density of keratocytes.

The mean posterior keratocyte density was $504 \pm 80$ cells $/ \mathrm{mm}^{2}$ for the noncontact lens wearing control group and $550 \pm 54$ cells $/ \mathrm{mm}^{2}$ for the moderate keratoconus group. There was a significantly greater keratocyte density in those with advanced keratoconus $\left(599 \pm 97\right.$ cells $\left./ \mathrm{mm}^{2}, P<0.001\right)$. The increase in keratocyte density with increasing keratoconus was significant $(P<0.05)$. In comparison to the contact lens wearing control group $\left(470 \pm 63\right.$ cells $\left./ \mathrm{mm}^{2}\right)$, the keratoconic group $(P=0.000)$ had a significantly higher density of keratocytes and the noncontact lens wearing control group demonstrated a nonsignificant tendency $(P=0.056)$.

There was a significant tendency for decreasing posterior keratocyte density with increasing age $(P<0.05)$. There was a significant reduction in keratocyte density from the anterior to the posterior stroma for all groups, however, the rate of decrease was significantly higher in both keratoconic groups $(P<0.05)$ compared with the controls.

\section{Endothelium}

The mean endothelial density was $3043 \pm 264$ cells $/ \mathrm{mm}^{2}$ for the noncontact lens wearing control group. The presence of keratoconus did not affect the endothelial cell density which was $2888 \pm 380$ cells $/ \mathrm{mm}^{2}, P=0.16$ in those with moderate keratoconus and $2941 \pm 464$ cells / $\mathrm{mm}^{2}, P=0.54$ in those with advanced keratoconus. Age did, however, significantly affect the endothelial cell density for all groups, with a decrease in cell density with increasing age $(P=0.001)$. The mean endothelial size $(\mu \mathrm{m})$ was not significantly different $(P=0.18)$ for any of the groups $(328 \pm 32$ for the control group and $348 \pm 23$ for the keratoconus group). Age did, however, significantly affect the endothelial cell size, with an increase in cell size $(P<0.01)$ with increasing age for all groups. 


\section{Discussion}

Within the literature there are two main theories in relation to the role of keratocytes in the development in keratoconus: keratocyte apoptosis or the modification of substances synthesised or expressed by the keratocytes. Additionally, contact lens wear in itself may ${ }^{11-14}$ influence the corneal keratocyte population. During corneal development keratocytes are responsible for the production of the corneal collagen fibrils and mucopolysaccharides that comprise the ground substance. The collagen fibrils are organised parallel to each other within each lamella and it is possible that keratocytes are responsible for tethering these lamellae in order to maintain the correct spatial anatomical relationship. Indeed, keratocyte cell thickness is influenced by the physical pressure exerted by adjacent stromal lamellae. ${ }^{15}$ From biomechanical studies, interlacing collagen lamellae within the human cornea appear to be an important factor in the cohesive and tensile strength of the cornea ${ }^{16}$ especially within the anterior stroma. ${ }^{17}$

Disappearance of anterior keratocytes following epithelial injury ${ }^{18}$ is mediated by apoptosis (programmed cell death), which is induced by the interleukin-1 (IL-1) system. Such injury can be due to mechanical forces such as contact lens wear and/or eye rubbing, both of which have been cited as possible aetiological factors in keratoconus. ${ }^{2}$ In our study there was a reduction in basal epithelium density within the keratoconic corneas. Hollingsworth et $a l^{19,20}$ also demonstrated this reduction and found similar difficulties in obtaining consistent imaging of the superficial epithelial layers. These authors also reported evidence of epithelial elongation, although this was not seen in our study this could be due to differences in experimental methodology. Hollingsworth et $a l^{19,20}$ imaged the central cornea while our study examined the corneal apex (except in three cases where stromal scarring prevented good visualisation at the apex)

Greiner et al, ${ }^{21}$ however, demonstrated that in a rabbit model, eye rubbing caused alterations to the epithelium of the upper tarsal conjunctiva and not to the squamous epithelium of the cornea. Perhaps the greater epithelial fragility of keratoconics is the differentiating factor, ${ }^{22}$ as the epithelium has been shown to be involved with keratoconus development. ${ }^{23,24}$ Bureau et al ${ }^{25}$ demonstrated that keratocytes from keratoconic corneas have a greater number of IL-1 receptors than normal. This increased expression of the IL-1 receptor may sensitise the keratocytes to IL-1 from the epithelium, thereby causing keratoctye apoptosis and a subsequent decrease in stromal mass over time. ${ }^{26}$ Keratoconic corneal tissue examined histopathologically supports apoptosis as the mode of cell death. ${ }^{27,28}$

Although the contact lens association with stromal hypoxia, hypercarnia, and thinning has been well documented, ${ }^{29-32}$ there is conflict within the reported in vivo confocal literature as to how contact lens wear affects the corneal keratocyte (see Table $1^{11-14,33-35}$ ). Variations in the reported number of keratocytes may be due to the contact lens type worn, the number of years wear and/or wearing schedule or even the type of in vivo confocal microscope used.

Jalbert and Stapleton ${ }^{13}$ and Efron et al, ${ }^{12}$ in assessing extended soft contact lens wear, both found reduction in keratocyte density in the posterior stroma within normal corneas. Jalbert and Stapleton ${ }^{13}$ additionally demonstrated a reduction in the anterior stroma as well, as did Bansal et $a l^{11}$ using a mix of contact lens types. Kallinikos and Efron ${ }^{14}$ also reported significant decreases in anterior and posterior keratocyte densities as a result of soft and rigid contact lens wear in neophytes after $2 \mathrm{~h}$ within an anoxic environment. However, Efron reported differently in a third study, this time with Hollingsworth and Efron, ${ }^{33}$ when they agreed with Patel et al ${ }^{34}$ who found no changes in anterior or posterior keratocyte density with normal corneas. All authors used a scanning slit in vivo confocal microscope, except Patel et $a l^{34}$ and Erie $e t a l^{35}$ who used a tandem scanning version.

Detecting the actual stromal depth of the confocal image is less accurate with the scanning slit than the tandem in vivo confocal ${ }^{34}$ and therefore it is possible that images in the anterior $10 \%$ of the stroma (where there is the highest density of keratocytes) could be variably included within the groups. Additionally, the measurements recorded by the scanning slit authors cite the density in $\mathrm{mm}^{2}$, whereas Patel et $a l^{34}$ and Erie et $a l^{35}$ report the volume in $\mathrm{mm}^{3}$. This variation becomes vital in interpretation of results when the corneal thickness measurements are different.

As the apical ectasia with keratoconus progresses there is a decrease in corneal thickness. ${ }^{2}$ In our study, corneal thickness was measured with the Orbscan which has been found to be noninvasive and reproducible, ${ }^{36,37}$ although it measures normal corneas to be thicker than with ultrasound devices (in the order of $28 \mu \mathrm{m}$ ). ${ }^{38,39}$ Within the literature, the definition of what constitutes early, mild, moderate, advanced, or severe keratoconus varies. ${ }^{40-43}$ In our study an empirical combination of corneal apex power ${ }^{44}$ and thickness was used. ${ }^{45}$ Therefore, in this context the in vivo confocal microscopy data may not always be readily correlated with the small number of published studies on the topic.

Erie et al ${ }^{35}$ observed that the decrease in the keratocyte density, in a study of mild to moderate keratoconus was only in association with contact lens wear. As, all our 
Table 1 Effect of contact lens wear on stromal keratocyte densities

\begin{tabular}{|c|c|c|c|c|c|c|c|c|}
\hline & Bansal et $a l^{11}$ & $\begin{array}{l}\text { Jalbert and } \\
\text { Stapleton }{ }^{13}\end{array}$ & Efron $e t a l^{12}$ & Patel et $a l^{34}$ & Erie $e t a l^{35}$ & $\begin{array}{l}\text { Kallinikos and } \\
\text { Efron }^{14}\end{array}$ & $\begin{array}{l}\text { Hollingsworth } \\
\text { and Efron }{ }^{33}\end{array}$ & Weed et al \\
\hline In vivo confocal microscope & Scanning slit & Scanning slit & Scanning slit & Tandem scanning & Tandem scanning & Tandem scanning & Tandem scanning & Scanning slit \\
\hline Contact lens normals & $\begin{array}{l}\text { Soft } n=18 \\
\text { RGP } n=15 \\
\text { PMMA } n=6\end{array}$ & $\begin{array}{l}\text { EW soft } \\
n=9\end{array}$ & $\begin{array}{l}\text { EW soft } \\
n=23\end{array}$ & $\begin{array}{l}\text { Soft } n=11 \\
\text { Mixed } n=6 \\
\text { RGP } n=2 \\
\text { PMMA } n=1\end{array}$ & $\begin{array}{l}\text { Soft } n=9 \\
\text { RGP } n=3\end{array}$ & $\begin{array}{l}\text { Soft } n=20 \\
\text { RGP } n=20\end{array}$ & RGP $n=22$ & $\begin{array}{l}\text { Soft } n=9 \\
\text { RGP } n=6\end{array}$ \\
\hline Non-CL wearers normals & $n=36$ & $n=9$ & N/A & $n=20$ & $n=17$ & $n=20$ & $n=22$ & $n=23$ \\
\hline keratoconus & N/A & N/A & N/A & $\mathrm{N} / \mathrm{A}$ & $n=17$ & $\mathrm{~N} / \mathrm{A}$ & $\mathrm{N} / \mathrm{A}$ & $\mathrm{N} / \mathrm{A}$ \\
\hline Contact lens keratoconus & N/A & $\mathrm{N} / \mathrm{A}$ & N/A & N/A & $\begin{array}{l}\text { RGP } n=9 \\
\text { soft } n=3\end{array}$ & $\mathrm{~N} / \mathrm{A}$ & $\mathrm{N} / \mathrm{A}$ & $\begin{array}{l}\text { RGP } \\
n=19\end{array}$ \\
\hline $\begin{array}{l}\text { Age CL } \\
\text { (years) }\end{array}$ & $\begin{array}{l}37 \\
(23-57)\end{array}$ & $\begin{array}{l}35 \\
(25-43)\end{array}$ & 23 & $\begin{array}{l}38 \\
(25-54)\end{array}$ & $\begin{array}{l}40 \\
(20-70)\end{array}$ & 26 & 44 & $\begin{array}{l}29 \\
(18-41)\end{array}$ \\
\hline $\begin{array}{l}\text { Age non-CL } \\
\text { (years) }\end{array}$ & $\begin{array}{l}38 \\
(20-73)\end{array}$ & $\begin{array}{l}36 \\
(31-40)\end{array}$ & N/A & $\begin{array}{l}37 \\
(26-50)\end{array}$ & $\begin{array}{l}39 \\
(20-72)\end{array}$ & 26 & $\mathrm{~N} / \mathrm{A}$ & $\begin{array}{l}38 \\
(20-58)\end{array}$ \\
\hline Number years wear normals & & $\begin{array}{l}5.9 \\
(5.3-6.5)\end{array}$ & 6 months & $\begin{array}{l}18.1 \\
(10-33)\end{array}$ & $\begin{array}{l}6 \\
(2-18)\end{array}$ & $\begin{array}{l}2 \mathrm{~h} \\
\text { anoxia }\end{array}$ & $\begin{array}{l}22 \\
(6-30)\end{array}$ & $\begin{array}{l}7 \\
(1-15)\end{array}$ \\
\hline Number years wear keratoconus & $\mathrm{N} / \mathrm{A}$ & $\mathrm{N} / \mathrm{A}$ & $\mathrm{N} / \mathrm{A}$ & $\mathrm{N} / \mathrm{A}$ & $\begin{array}{l}7 \\
(2-30)\end{array}$ & $\mathrm{N} / \mathrm{A}$ & N/A & $\begin{array}{l}11 \\
(2-35)\end{array}$ \\
\hline $\begin{array}{l}\text { Normals } \\
\text { ASK CL }\end{array}$ & $757 \mathrm{~mm}^{2}$ & $544 \mathrm{~mm}^{2}$ & $1112 \mathrm{~mm}^{2}$ & $\begin{array}{l}30.545 \mathrm{~mm}^{3} \\
32056 \mathrm{~mm}^{3}\end{array}$ & $35630 \mathrm{~mm}^{3}$ & See & $958 \mathrm{~mm}^{2}$ & $609 \mathrm{~mm}^{2}$ \\
\hline $\begin{array}{l}\text { ASK non-CL } \\
\text { Keratoconus }\end{array}$ & $925 \mathrm{~mm}^{2}$ & $804 \mathrm{~mm}^{2}$ & N/A & $\mathrm{N} / \mathrm{A}$ & $31168 \mathrm{~mm}^{3}$ & graph & $1028 \mathrm{~mm}^{2}$ & $761 \mathrm{~mm}^{2}$ \\
\hline $\begin{array}{l}\text { ASK CL } \\
\text { ASK non-CL }\end{array}$ & $\begin{array}{l}\text { N/A } \\
\text { N/A }\end{array}$ & $\begin{array}{l}\text { N/A } \\
\text { N/A }\end{array}$ & $\begin{array}{l}\text { N/A } \\
\text { N/A }\end{array}$ & $\mathrm{N} / \mathrm{A}$ & $\begin{array}{l}24564 \mathrm{~mm}^{3} \\
32724 \mathrm{~mm}^{3}\end{array}$ & & $\begin{array}{l}\text { N/A } \\
\text { N/A }\end{array}$ & $\begin{array}{l}883 / 952 \\
\text { N/A }\end{array}$ \\
\hline $\begin{array}{l}\text { Normals } \\
\text { PSK CL }\end{array}$ & & & & & & & & \\
\hline & N/A & $628 \mathrm{~mm}^{2}$ & $\mathrm{~N} / \mathrm{A}$ & $20920 \mathrm{~mm}^{3}$ & $18129 \mathrm{~mm}^{3}$ & $\begin{array}{l}\text { See } \\
\text { graph }\end{array}$ & $\begin{array}{l}580 \mathrm{~mm}^{2} \\
557 \mathrm{~mm}^{2}\end{array}$ & $\begin{array}{l}4 / 0 \mathrm{~mm}^{2} \\
504 \mathrm{~mm}^{2}\end{array}$ \\
\hline PSK CL & $\mathrm{N} / \mathrm{A}$ & $\mathrm{N} / \mathrm{A}$ & $\mathrm{N} / \mathrm{A}$ & $\mathrm{N} / \mathrm{A}$ & $11118 \mathrm{~mm}^{3}$ & & $\mathrm{~N} / \mathrm{A}$ & $550 / 599$ \\
\hline PSK non-CL & N/A & $\mathrm{N} / \mathrm{A}$ & N/A & N/A & & & N/A & N/A \\
\hline Conclusion & $\begin{array}{l}\text { CL wear reduces } \\
\text { ASK density only } \\
\text { normal corneas }\end{array}$ & $\begin{array}{l}\text { EW soft CL } \\
\text { reduces A and } \\
\text { PSK density } \\
\text { normal corneas }\end{array}$ & $\begin{array}{l}\text { CL wear reduces } \\
\text { PSK density only } \\
\text { normal corneas }\end{array}$ & $\begin{array}{l}\text { Daily CL no effect } \\
\text { on normal corneas } \\
\text { A or PSK density }\end{array}$ & $\begin{array}{l}\text { Decrease A and } \\
\text { PSK density with } \\
\text { CL wear only } \\
\text { with Keratoconus }\end{array}$ & $\begin{array}{l}\text { RGP and soft CL } \\
\text { wear reduces A } \\
\text { and PSK density } \\
\text { normal corneas }\end{array}$ & $\begin{array}{l}\text { RGP CL no effect } \\
\text { on A or PSK } \\
\text { density normal } \\
\text { corneas }\end{array}$ & $\begin{array}{l}\text { CL wear reduces } \\
\text { ASK density } \\
\text { normal corneas }\end{array}$ \\
\hline
\end{tabular}


subjects needed to wear contact lenses for visual rehabilitation and exhibited corneal signs of keratoconus, including corneal scarring, the mean corneal thickness was considerably less $(429 \pm 72 \mu \mathrm{m})$ in comparison to Erie $e a^{35}$ since the keratoconic populations are different in their severity. The difference in corneal thickness may account for the differences in the results. Within our study, as the corneal protrusion advanced the corneal thickness decreased compressing the keratocytes within the stroma at the corneal apex, the measured density will increase for the same confocal slice thickness.

However, between the control groups, contact lens wear per se was associated with a significantly reduced anterior keratocyte density and demonstrated a reduction trend toward reduced keratocyte density in the posterior stroma. These data support most of the existing data in 'normal' eyes; ${ }^{11-14}$ however, it is at variance with the postulate of Erie $e t a l^{35}$ that only diseased eyes demonstrate keratocyte reduction with contact lens wear. Unfortunately, there were no moderate or advanced keratoconics who had not worn contact lenses to compare the effects of contact lens wear with keratoconus in our study.

In a very recent series of in vivo confocal microscopy studies, Hollingsworth et al $l^{8,19,20,46}$ have provided novel data with which the current study can be compared. One important difference between the two studies previously commented on is the corneal location examined (central cornea $^{19,20}$ vs corneal apex). Keratocyte cell density may not be uniform across the keratoconic cornea and this may explain the higher anterior and posterior keratocyte densities reported in our study. Additionally, the keratoconic group examined by Hollingsworth et $a l^{20}$ also included a mixture of contact lens wearers and noncontact lens wearers and was compared to a noncontact lens wearing control group while in our study, only keratoconic contact lens wearers were examined and the stromal keratocyte density was compared with two control groups (contact lens and non contact lens wearers) separately.

The keratocyte shape is specific for corneal location. ${ }^{47}$ In the anterior stroma the keratocyte nuclei are more ellipsoid, whereas in the posterior stroma the nuclei appeared more elongated/spindle-shaped (Figures 4 and 5 , respectively). This regional difference has been reported elsewhere, ${ }^{8}$ although Poole et $a l^{48}$ reported the exact opposite. The functional relevance of these regional keratocyte shapes is unknown, although it has been hypothesised that different keratocytes produce different substances. ${ }^{49}$ This is supported by the nonuniform proteoglycan distribution within the stroma. ${ }^{50}$

The production of abnormal substances within the keratoconic stroma previously has been reported: with abnormal production of matrix metalloproteinase-2,; upregulation of the expression of MT1-MMP; ${ }^{52}$ overexpression of keratocan; ${ }^{53}$ reduction in expression of type X11 collagen ${ }^{54}$ and modification of type V1 collagen synthesis ${ }^{55}$ all being documented. Although keratocytes appear to provide a vital role in the stability of the corneal structure, ${ }^{17}$ perhaps the corneal changes exhibited by keratoconics are due to substances synthesised or expressed by keratocytes.

In this study, the anterior and posterior stromal keratocytes in the control group are similar to that reported within the literature ${ }^{56,57}$ and the reduction in keratocyte density from the anterior to the posterior stroma is widely recognised. ${ }^{58-62}$ Keratoctye density, in addition, has been reported to decrease with increasing age, ${ }^{60,62,64}$ however, other authors ${ }^{57,63}$ have reported consistency in the corneal keratocyte populations throughout life. In this study, reduction in keratocyte density with age was found to be significant in the posterior stroma only, with a strong trend within the anterior stroma.

The corneal endothelium is a monolayer of polygonal cells, the density of which is highest at birth (more than 3000 cells $\left./ \mathrm{mm}^{2}\right)^{65}$ and steadily reduces slowly with age. ${ }^{66}$ This reduction with age was significant in the keratoconic and control group in our study. Anecdotally, we observed polymegathism (variability in cell size) and pleomorphism (variability in cell shape) within the keratoconic group (control group were non contact lens wearers). Additionally, there was an apparent decrease in the frequency of hexagonal cell shapes within the endothelium, all of which has been previously reported elsewhere with keratoconics. ${ }^{20,67-69}$ Similar observations have been documented within 'normal' corneal endothelium due to the presence of contact lens wear. ${ }^{70}$ We found no difference in endothelial density between the keratoconic group and the control group (age was included as a covariate), which differs from Hollingsworth et $a l^{20}$ who reported a higher endothelial density within the keratoconic group. This could be due to differing keratoconic populations in age and disease composition and with the experimental corneal location differences.

Limitations of this part of the study include (a) data being interpreted by an unmasked observer and (b) the problem of identifying where exactly the image is located in the $X, Y$ and $Z$ axes of the cornea. Using randomised images examined by a masked observer would eliminate the potential observer bias, however, this was not feasible. Anterior stromal data were taken from the region of tissue that comes into focus immediately posterior to Bowman's layer and similarly the posterior stroma data were taken from the video image immediately anterior to the endothelial layer, in order to minimise error in depth ( $Z$ axis) location. 
Progression of subclinical keratoconus has been identified by serial corneal topography analysis. ${ }^{71}$ Further in vivo confocal study is needed to follow patients with keratoconus from diagnosis to the end stage. Changes within the cornea can then be compared at varying stages of the disease especially the interplay between corneal thickness and keratocyte density. The impact of soft contact lenses on the cornea has been demonstrated by a monozygotic twin study. ${ }^{72}$ Indeed, the majority of work on this subject (including this study) supports a degree of corneal thinning in association with contact lens within normal corneas. ${ }^{73}$ To distinguish the effects of contact lens wear from the disease process of keratoconus, ideally, true unilateral keratoconics might be required to wear contact lenses in both eyes.

Additionally, in order to identify the effect of keratocyte populations before transplantation, in vivo confocal microscopy needs to be performed on advanced cones before trephination for corneal transplantation and then the data compared with the ex vivo confocal microscopy on the corneal button postoperatively. Conversely, ex vivo analysis of the corneal button before PKP followed by in vivo confocal microscopy of the transplant over time might provide interesting data in regard to changes in the donor keratocyte population postgraft.

The heterogeneity in keratoconus may explain the contradictory data that exist in the literature. ${ }^{74}$ In vivo confocal microscopy can provide greater insight into the morphological changes that occur with this progressive noninflammatory corneal ectasia. By improving our understanding of keratoconus this may enable alternative therapies to be devised in order to retard its progression and therefore reduce the need for surgical intervention.

\section{Acknowledgements}

The in vivo confocal microscope was purchased by a MRC joint research equipment initiative Grant with Bausch and Lomb (UK). The main source of funding was by a Royal College of Surgeons of Edinburgh Grant. Additional support was given by an unrestricted Grant from the Speed Pollock Memorial Fund and an Anonymous Grant from NHS Tayside Trust.

The contact lens control confocal data was presented at the Oxford Ophthalmological Congress 2004. The keratoconic data was presented at the College of Ophthalmology Annual Meeting 2005.

\section{References}

1 Krachmer JH, Feder RS, Belin MW. Keratoconus and related non-inflammatory corneal thinning disorders. Surv Ophthalmol 1984; 28(4): 293-322.
2 Rabinowitz YS. Keratoconus. Surv Ophthalmol 1998; 42: 297-319.

3 Edwards M, McGhee CNJ, Dean S. The genetics of keratoconus. Clin Exp Ophthalmol 2001; 29(6): 345-351.

4 Rabinowitz YS, Nesburn AB, McDonnell PJ. Video keratography of the fellow eye in unilateral keratoconus. Ophthalmology 1993; 100: 181-186.

5 Weed KH, McGhee CNJ. Keratoconus: referral patterns, treatment management and visual outcome in keratoconus. Eye 1998; 12: 663-668.

6 Sray WA, Cohen EJ, Rapuano CJ, Laibson PR. Factors associated with the need for penetrating keratoplasty in keratoconus. Cornea 2002; 21(8): 784-786.

7 Somodi S, Hahnel C, Slowik C, Richter A, Weiss DG, Guthoff R. Confocal in vivo microscopy and confocal laser-scanning fluorescence microscopy in keratoconus. Ger J Ophthalmol 1996; 6: 518-525.

8 Hollingsworth JG, Efron N. Observations of banding patterns (Vogt striae) in keratoconus: a confocal microscopy study. Cornea 2005; 24(2): 162-166.

9 Wiegand W, Thaer AA, Kroll P, Geyer OC, Garoa AJ. Optical sectioning of the cornea with a new confocal in vivo slit scanning video microscope. Ophthalmology 1995; 102 568-575.

10 Bohnke M, Masters BR. Confocal microscopy of the cornea. Prog Ret Eye Res 1999; 18: 553-628.

11 Bansal AK, Mustonen RK, McDonald MB. High resolution in vivo scanning confocal microscopy of the cornea in long term contact lens wear. Inv Ophthalmol Vis Sci 1997; 38(4): 5674 B585.

12 Efron N, Perez-Gomez I, Morgan PB. Confocal microscopic observations of stromal keratocytes during extended contact lens wear. Clin Exp Optom 2002; 85(3): 156-160.

13 Jalbert I, Stapleton F. Effect of lens wear on corneal stroma: preliminary findings. Aust NZ J Ophthalmol 1999; 27(3-4): 211-213.

14 Kallinikos P, Efron N. On the etiology of keratocyte loss during contact lens wear. Invest Ophthalmol Vis Sci 2004; 45(9): 3011-3020.

15 Doughty MJ, Seabert W, Bergmanson JPG, Blocker Y. A descriptive and quantitative study of the keratocytes of the corneal stroma of albino rabbits using transmission electron microscopy. Tissue and Cell 2001; 33(4): 408-422.

16 Radner W, Zehetmayer M, Aufreiter R, Mallinger R. Interlacing and cross-angle distribution of collagen lamellae in the human cornea. Cornea 1998; 17: 537-543.

17 Muller LJ, Pels E, Vrensen GF. The specific architecture of the anterior stroma accounts for maintenance of corneal curvature. Br J Ophthalmol 2001; 85: 379-381.

18 Kim WJ, Helena MC, Mohan RR, Wilson SE. Changes in corneal morphology associated with chronic epithelial injury. Invest Ophthalmol Vis Sci 1999; 40: 35-42.

19 Hollingsworth JG, Bonshek RE, Efron N. Correlation of the appearance of the keratoconic cornea in vivo by confocal microscopy and in vitro by light microscopy. Cornea 2005; 24(4): 397-405.

20 Hollingsworth JG, Efron N, Tullo A. In vivo corneal confocal microscopy in keratoconus. Ophthalmic Physiol Opt 2005; 24(93): 254-260.

21 Greiner JV, Leahy CD, Welter DA, Hearn SL, Weidman TA, Korb DR. Histology of the ocular surface after eye rubbing. Cornea 1997; 16(3): 327-332.

22 Millodot M, Owens H. Sensitivity and fragility in keratoconus. Acta Ophthalmol 1983; 61: 908-917. 
23 Maruyama Y, Wang W, Li Y, Sugar J, Yue BY. Involvement of Sp1 elements in the promoter activity of genes affected in keratoconus. Invest Ophthalmol Vis Sci 2001; 42(9): 1980-1985.

24 Nielsen K, Birkenkamp-Demtroder K, Ehlers N, Orntoft TF. Identification of differentially expressed genes in keratoconus epithelium analyzed on micro-arrays. Invest Opthalmol Vis Sci 2003; 44(6): 2466-2476.

25 Bureau J, Fabre EJ, Hecquet C, Pouliquen Y, Lorans G. Modification of prostaglandin $\mathrm{E}_{2}$ and collagen synthesis in keratoconus fibroblasts associated with an increase of interleukin-1 alpha receptor number. CR Acad Sci III 1993; 316: 425-430.

26 Wilson SE, He YG, Weng J, Li O, McDonnall AW, Vital M et al. Epithelial injury induces keratocyte apoptosis: hypothesized role for the interleukin - 1 system in the modulation of corneal tissue organization and wound healing. Exp Eye Res 1996; 62: 325-327.

27 Kim WJ, Rabinowitz YS, Meisler DM, Wilson SE. Keratocyte apoptosis associated with keratoconus. Exp Eye Res 1999; 69: 475-481.

28 Kaldawy RM, Wagner J, Ching S, Seigel GM. Evidence of apoptotic cell death in keratoconus. Cornea 2002; 21: 206-209.

29 Liesegang TJ. Physiologic changes of the cornea with contact lens wear. CLAO J 2002; 28(1): 12-27.

30 Bergmanson JPG, Chu LWF. Corneal response to rigid contact lens wear. Br J Ophthalmol 1982; 66: 667-675.

31 Holden BA, Sweeney DF. Contact lens can induce stromal thinning. Clin Exp Ophthalmol 1988; 71(4): 109-113.

32 Liu Z, Pflugfelder SC. The effects of long term contact wear on corneal thickness, curvature and surface regularity. Ophthalmology 2000; 107(1): 105-111.

33 Hollingsworth JG, Efron N. Confocal microscopy of the corneas of long term rigid contact lens wearers. Contact Lens Anterior Eye 2004; 27: 57-64.

34 Patel SV, McClaren JW, Hodge DO, Bourne WM. Confocal microscopy in vivo in corneas of long term contact lens wearers. Invest Ophthalmol Vis Sci 2002; 43: 995-1003.

35 Erie JC, Patel SV, McLaren JW. Keratocyte density in keratoconus. A confocal microscopy study. Am J Ophthalmol 2002; 134(5): 689-695. Comment in Am J Ophthalmol 2003;135(5):746-7; Author reply 747.

36 Liu Z, Huang AJ, Pflugfelder SC. Evaluation of corneal thickness and topography in normal eyes using the Orbscan corneal topography system. Br J Ophthalmol 1999; 83: 774-778.

37 Lattimore MR, Kaupp S, Schallhorn S, Lewis R. Orbscan pachymetry Implications of a repeated measures and diurnal variation analysis. Ophthalmology 1999; 106: 977-981.

38 Yaylali V, Kaufman SC, Thompson HW. Corneal thickness measurements with the Orbscan topography system and ultrasonic pachymetry. J Cataract Refract Surg 1997; 23: 1345-1350.

39 Chakrabarti HS, Craig JP, Brahma A, Malik TY, McGhee CNJ. Comparison of corneal thickness measurements using ultrasound and Orbscan slit-scanning topography in normal and post-LASIK eyes. J Cataract Refract Surg 2001; 27(11): 1823-1828.

40 Szczotka LB, Barr JT, Zadnik K. A summary of the findings from the collaborative longitudinal evaluation of keratoconus (CLEK) study. Optometry 2001; 72(9): 574-585.
41 Kastl PR, Donzis PB, Cole HP, Rice J, Baldone JA. A 20 year retrospective study of the use of contact lenses in keratoconus. CLAO J 1987; 13(2): 102-104.

42 Jimenez JLO, Jurado JCG, Rodriguez FJB, Laborda DS. Keratoconus: Age of onset and natural history. Optom Vis Sci 1997; 74(3): 147-151.

43 Watters GA, Owens H. Evaluation of mild, moderate and advanced keratoconus using ultrasound pachometry and the EyeSys Videokeratoscope. Optom Vis Sci 1998; 75(9): 640-646.

44 Smolek MK, Klyce SD. Current keratoconus detection methods compared with a neural network approach. Invest Ophthalmol Vis Sci 1997; 38: 2290-2299.

45 Owens H, Watters GA. An evaluation of the keratoconic cornea using computerised corneal mapping and ultrasonic measurements of corneal thickness. Ophthalmic Physiol Opt 1996; 16: 115-123.

46 Hollingsworth J, Perez-Gomez I, Mutalib HA, Efron N. A population study of the normal cornea using an in-vivo slit scanning confocal microscope. Optom Vis Sci 2001; 78(10): 706-711.

47 Muller LJ, Pels L, Vrensen GFJM. Normal aspects of the ultrastructural organization of human corneal keratocytes. Invest Ophthalmol Vis Sci 1995; 36: 2557-2567.

48 Poole CA, Brookes NH, Clover GM. The keratocyte network in porcine cornea using the confocal imaging of fixable vital dye 5-chloromethyl-fluorescein diacetate. Curr Eye Res 1996; 15: $165-174$.

49 Miller LJ, Pel SL, Vrensen GFJM. Normal aspects of the ultrastructural organization of human corneal keratocytes. Ophthalmol Vis Sci 1995; 36: 2557-2567.

50 Maurice DM. The cornea and sclera. In: Davson H (eds) The Eye. New York Academic Press: New York, 1984 pp 1-158.

51 Parkin BT, Smith VA, Easty DL. The control of matrix metalloproteinase-2 expression in normal and keratocyte cultures. Eur J Ophthalmol 2000; 10(4): 276-285.

52 Collier SA, Madigan MC, Penfold PL. Expression of membrane-type 1 matrix metalloproteinase (MT1-MMP) and MMP-2 in normal and keratoconus corneas. Curr Eye Res 2000; 21: 662-668.

53 Wentz-Hunter K, Cheng EL, Sugar J, Yue BYJT. Keratocan expression is increased in the stroma of keratoconus. Molecular Medicine 2001; 7: 470-477.

54 Cheng EL, Maruyama I, SundarRaj N, Sugar J, Peder RS, Yue BY. Expression of type X11 collagen and hemidesmosome associated proteins in keratoconus corneas. Curr Eye Res 2001; 22: 333-340.

55 Chwa M, Kenney MC, Khin H, Brown DJ. Altered type VI collagen synthesis by keratoconus keratocytes in vitro. Biochem Biophys Res Commun 1996; 224: 760-764.

56 Moller-Pedersen T, Ehlers N. A three-dimensional study of the human corneal keratocyte density. Curr Eye Res 1995; 14(6): 459-464.

57 Mustonen RK, McDonald MB, Scrivannaboon S, Tan AL, Doubrava MW, Kim CK. Normal human corneal cell populations evaluated by invivo scanning slit confocal microscopy. Cornea 1998; 17(5): 485-492.

58 Prydal JI, Franc F, Dilly PN, KerrMuir MG, Corbett MC, Marshall J. Keratocyte density and size in conscious humans by digital image analysis of confocal images. Eye 1998; 12: 337-342.

59 Patel S, McClaren J, Hodge D, Bourne W. Normal human keratocyte density and corneal thickness measurement by 
using confocal microscopy in vivo. Invest Ophthalmol Vis Sci 2001; 42: 333-339.

60 Hahnel C, Somodi S, Weiss DG, Guthoff RF. The keratocyte network of human cornea: a three dimensional study using confocal laser scanning fluorescence microscopy. Cornea 2000; 19: 185-193.

61 Cavanagh HD, Petoll M, Alizadeh H, He YG, McCulley JP, Jester JV. Clinical and diagnostic use of invivo confocal microscopy in patients with corneal disease. Ophthalmology 1993; 100: 144-1454.

62 Moller-Pedersen T. A comparative study of human corneal keratocyte and endothelial cell density during ageing. Cornea 1997; 16(3): 333-338.

63 Poole CA, Brookes NH, Clover GM. Confocal imaging of the human keratocyte network using the vital dye 5-chloromethyl-fluorescein diacetate. Clin Experiment Ophthalmol 2003; 31(2): 147-154.

64 Berlau J, Becker HH, Stave J, Oriwol C, Guthoff R. Depth and age-dependent distribution of keratocytes in healthy human corneas: a study using scanning-slit confocal microscopy in vivo (1). J Cataract Refract Surg 2002; 28 611-616.

65 Waring GO, Bourne WM, Edelhauser HF, Kenyon KR. The corneal endothelium: normal and pathologic structure and function. Ophthalmology 1982; 89: 531-590.

66 Bourne WM, Kaufman HE. Specular microscopy of human corneal endothelium in vivo. Am J Ophthalmol 1976; 81: 319-326.
67 Matsuda M, Suda T, Manabe R. Quantitative analysis of endothelial mosaic pattern changes in anterior keratoconus. Am J Ophthalmol 1984; 98: 43-49.

68 Laing RA, Sandstrom MM, Berropsi AR, Leibowitz HM The human corneal endothelium in keratoconus: a specular microscopic study. Arch Ophthalmol 1979; 97: 1867-1869.

69 Halabais JA. Analysis of the corneal endothelium in keratoconus. Am J Optom Physiol Opt 1987; 64: 51-53.

70 Yamauchi K, Hirst LW, Enger C et al. Specular microscopy of hard contact lens wearers 11. Ophthalmology 1989; 96: 1176-1179.

71 Maguire LJ, Lowry JC. Identifying progression of subclinical keratoconus by serial topography analysis. Am J Ophthalmol 1991; 112: 41-45.

72 Sanchis-Gimeno J, Lleo A, Alonso L, Rallal MS, MartinezSoriano F. Differences in corneal anatomy in a pair of monozygotic twins due to continuous contact lens wear. Cornea 2003; 22(3): 243-245.

73 Pflugfelder SC, Liu Z, Feuer W, Verm A. Corneal thickness indices discriminate between keratoconus and contact lens induced corneal thinning. Ophthalmology 2002; 109: 2336-2341.

74 Yue BY, Sugar J, Benveniste K. Heterogeneity in keratoconus: possible biochemical basis. Proc Soc Exp Biol Med 1984; 175(3): 336-341. 